\title{
A Study on Grammar Teaching at an English Education Department in an EFL Context
}

\author{
Muh. Saeful Effendi, Umi Rokhyati, Uchti Al-Muchanifah Rachman, \\ Aulia Dwi Rakhmawati, Dati Pertiwi
}

English Education Department, Universitas Ahmad Dahlan

\begin{abstract}
This research is the study of Grammar teaching in an English Education Department. The purposes of this study are: to find out the approach used in teaching grammar, to describe the difficulties encountered by students in studying grammar, and to find out the students' grammar ability. The research was conducted by lecturers and students who are doing research for their graduating paper. The population is students of English Education. Sample was taken using the technique of random according to Krejcie and Morgan table. The instruments used to collect data are tests, observation sheets and questionnaires. The results showed that there are several approaches used in teaching Grammar by the lecturers at the beginning of the semester. They are deductive, inductive, structural and communicative approaches. The problems faced by students in learning grammar are problems related to natural difficulties, mother tongue, students' aspects, lecturers' aspects, and the method and timing aspects. The next finding from this study is students' grammar mastery. It was found out that the grammar mastery of students who have taken all grammar subjects is in fair level.
\end{abstract}

Keywords: grammar, approach, difficulty, mastery

\section{INTRODUCTION}

Grammar is an important element of a language. Mastering the grammar of a language will affect the mastery of language skills. Therefore, in studying language formally, grammar is a subject that should be studied in depth. The students need to be given adequate provision of grammar so that they have good language skills.

Grammar, for many students, is considered a difficult and unattractive subject. They do not like learning grammar and therefore they cannot have good achievement in learning it. Even students who have learnt grammar for some years in college still get difficulty to construct good and correct sentences. Some students still make grammar mistakes when they write their graduating paper and lecturers have to work hard helping them correcting the mistakes.

This study is conducted in that situation above. The aims of the study comprise the followings.

1. Finding out the approaches used by the lecturers in teaching grammar.

2. Outlining the difficulties encountered by students in studying grammar.

3. Explaining the grammar mastery levels of the students.

\section{LITERATURE REVIEW}

\subsection{Grammar}

There are several definitions of grammar. First, according to Richards and Schmidt (2010: 251-252) grammar is a description of the structure of a language and how language units such as words and phrases are formed into sentences. The next definition, grammar is a set of rules or principles of the working of a language, its system or structure (Brinton, 2000: 8). While Yule stated that grammar is the process of describing the structure of phrases and sentences by considering its order in a language (2006: 74). In addition to these definitions of grammar, Weaver divides grammar into two definitions. First, grammar is a description of the syntax of a language, and the second is a set of rules or prescription of how to use language (1996: 1-2). 
Meanwhile Larsen-Freeman (2009:518) states that the definition of grammar when associated with language learning has some meanings. They are:

a. mental systems that generate and interpret novel utterances

b. a set of prescription and proscription about language forms and their use for a particular language

c. description of language behaviour by proficient users of a language

d. the focus of a given linguistic theory

e. a work that treats a major structures of a language

f. structures and rules that are compiled for instructional and assessment purposes

g. structures and rules that are compiled for instructional purposes of the teacher

From the definition described above a conclusion can be drawn that grammar has always been the elements of a language and the rules of how to arrange these elements into a meaningful unit. For example: how words are arranged into phrases and how phrases are arranged into sentences.

Grammar can be grouped into several types. Cook (2008: 19-24) classifies grammar into 5 (five) types, namely:

1. Prescriptive grammar: is a way to explain how someone should say something, not explaining how someone says something.

2. Traditional grammar: a system of how sentence structures are used in schools, based on the classical language grammar.

3. Structural Grammar: a system for describing language sentence based on the preparation of smaller structures into a larger structure.

4. Linguistic/grammatical competence: seen from this angle, grammar is the knowledge of a person (speaker) about the structure of a language that has regularity. The owner of a language knows how to use grammar without studying it.

5. EFL grammar: a person who is not a native speaker of a language will know the grammar of a language by studying it. Therefore this type combines elements of traditional and structural grammar.

\subsection{Learning Grammar}

Grammar is one of the language aspects. Therefore someone who learns a new language formally, in general, will be given grammar lessons. Of course this depends on the level of the students who are learning. Learning Grammar is an important activity in language learning. According to the study of language learning which includes a focus on learning grammar (form-focused instruction), grammar teaching convincingly shows more effective results than teaching focusing only on the meaning. Learning focuses on grammar, according to Long can be divided in two. The first FOFs (focus on forms) and FoF (focus on form). The first model of learning focused on studying grammar. In this model, the grammar is taught separately from the context. The second model of learning is focused on the meaning and on the grammar that appears on the material being studied (Nassaji and Fotos, 2007: 11-12).

According to Harmer (2007: 81-82) in the learning of grammar, there are two common approaches contrasted: deductive and inductive approach. In the deductive approach to learning grammar, students will be given an explanation or grammar formulas. Based on this explanation students then create a phrase or sentence in the language he had learned. Inductive approach is the opposite of the deductive approach. On learning grammar with inductive approach students do not learn the formula used but students are given examples of sentences first. From these examples students will try to find the formulas of the sentences.

\subsection{Problems in Learning Grammar}

According to Ellis (2009: 144) the difficulty in learning grammar can be grouped into three, namely: the difficulties associated with environmental factors of language, with linguistic factors, and psychological difficulties. Factors related to language environment are how often the input obtained from the environment. Linguistic factor refers to the nature of the grammar of a language and psychological factors refer to the ability to learn. 


\section{METHOD}

The study is descriptive in nature. The data obtained are analyzed using quantitative and qualitative analysis. The research population is English department students in semester 2, 4, and 6. Samples were taken randomly. The number taken is based on Krejcie and Morgan table. For the second semester students who take the Intermediate Structure with the population of 250 and the sample was 152 students. For the fourth semester students, the population was 183 students and used as samples was 123 . The 6th semester student population of 212 is used as a sample of 140 .

The technique used to collect data includes observation in the classroom, testing, and distributing questionnaire. Observation technique was used to observe the approach taken by the lecturers in teaching grammar. The test was used to obtain data on student mastery of grammar and to know the difficulties of students in grammar.

\section{RESUlT}

\subsection{The Approaches Applied}

To know the approaches used in teaching grammar, the data were collected through observing the teaching and learning process in the Intermediate Structure class of Semester 2. The subjects were six lecturers who taught at the level studied. Instruments for collecting data are observation, questionnaires, and interviews. The results showed that the approaches used in teaching grammar by the lecturers are deductive approach, Inductive Approach, Structural Approach and Communicative Approach.

Table IV.1. The approach used in teaching Grammar

\begin{tabular}{|c|c|c|c|c|}
\hline Approach & Deductive & Inductive & Structural & Communicative \\
\hline Lecturer & & & & \\
\hline AT & $\mathrm{v}$ & $\mathrm{v}$ & & \\
\hline MT & $\mathrm{v}$ & $\mathrm{v}$ & & \\
\hline IN & & $\mathrm{v}$ & & \\
\hline TR & $\mathrm{v}$ & & & $\mathrm{v}$ \\
\hline $\mathrm{KH}$ & & & & $\mathrm{V}$ \\
\hline PR & & & $\mathrm{v}$ & \\
\hline
\end{tabular}

The use of each approach depends on the material being taught, the nature of the students, the students' needs and abilities, and the learning objectives. The approach used by the lecturer in each class may be different depending on the class situation. Lecturers also use more than one approach in the classroom or use the same approach in a different class.

Students have the perception that the approach used by lecturers was appropriate with their needs.

On the other hand, the students stated that from the approach used students prefer a deductive approach. This can be seen in the following table.

Students' Preference of Approach

\begin{tabular}{|l|l|c|c|}
\hline No & \multicolumn{1}{|c|}{ Questions } & Yes & No \\
\hline 1 & Is the way of way teaching grammar suitable for you? & $80 \%$ & $20 \%$ \\
\hline 2 & Do you like learning grammar by receiving explanation of grammar rules first? & $73 \%$ & $27 \%$ \\
\hline 3 & $\begin{array}{l}\text { Do you like learning grammar by being asked to understand text first then } \\
\text { followed by grammar rules explanation? }\end{array}$ & $27 \%$ & $73 \%$ \\
\hline
\end{tabular}

\subsection{Students' Difficulties in Learning Grammar}

The study aims to determine the mastery of grammar and the problems experienced by students in the study of Grammar. The study was conducted in Advanced Structure class in Semester 4. The number of respondents was 123 students. The instrument used was a test (to determine the ability of grammar) and interviews to explore problems faced. The results revealed that the students have a good mastery of grammar. The difficulties encountered by the students were linguistic and non-linguistic ones. They comprise: 1. The difference in structure of the English and Indonesian languages makes the students get difficulty to understand the structure of English and to write in English 2. The occurrence of interference in using the English language. Students write sentences in Indonesian first before writing a sentence in English. 3. Some students (20\%) stated they learn in English department not because they want to. So, they lack of the motivation to follow the course. 4. Students are less active in asking questions in class $(59 \%)$.. 


\subsection{Students' Grammar Mastery}

The data were taken from students in Semester 6. They have completed all of the structure / grammar courses. The research objective was to determine student mastery of Grammar after studying all the material that was taught from the 1 st semester to 5 th semester. The number of respondents in this study was 140 students. The research instrument was a test that included grammar material of the 1st semester to $5^{\text {th }}$. The results showed that students' mastery of Grammar was categorized in fair level. It can be seen in the table below.

Students' Mastery of Grammar

\begin{tabular}{|c|c|c|c|}
\hline Score Interval & Frequency & Percentage & Category \\
\hline $10-8.3$ & 9 & $6.42 \%$ & Very Good \\
\hline $8.2-6.8$ & 38 & $27.14 \%$ & Good \\
\hline $6.7-5.4$ & 43 & $30.72 \%$ & Fair \\
\hline $5.3-3.9$ & 40 & $28.57 \%$ & Poor \\
\hline $3.8-0$ & 10 & $7.14 \%$ & Very Poor \\
\hline TOTAL & 140 & $100 \%$ & \\
\hline
\end{tabular}

When examined in detail the data of the students' mastery of grammar showed that the lower the level of the course the better grammar mastery the students obtain. The level of mastery of the easiest to the most difficult part is as follows:

Level of Grammar Mastery

\begin{tabular}{|c|c|c|}
\hline No. & Structure Class & The level of grammar mastery \\
\hline 1. & Advanced Structure & Thy lowest \\
\hline 2. & Pre-Advanced Structure & \\
\hline 3. & Intermediate Structure & \\
\hline 4. & Pre-Intermediate Structure & The highest mastery \\
\hline 5. & Basic Structure & \\
\hline
\end{tabular}

The difficulties that the students found in grammatical items are shown in the following table.

Students' Problems in Grammatical Items

\begin{tabular}{|l|l|l|}
\hline No & Level Grammar & Kesulitan grammar yang ditemukan \\
\hline 1. & Basic Structure & Adverb \\
\hline 2. & Pre-Intermediate Structure & Prepositional phrases \\
\hline 3. & Intermediate Structure & Noun clauses: Subjunctive statements \\
\hline 4. & Pre-Advanced Structure & Tenses \\
\hline 5. & Advanced Structure & Complex sentences with adverbial clauses \\
\hline
\end{tabular}

\section{DiSCUSSION}

\subsection{Students' Difficulties in Learning Grammar}

The findings from this study indicate that students find difficulty in learning the grammar. Of the 123 students who was studied, $92 \%$ said that the structure of the English language is very different from the structure of the Indonesian. However, only $56 \%$ state that they get difficulty in understanding the English structure. This means that differences between the two languages led to complications for $56 \%$ of the students. They are still experiencing difficulties related to the morphology and syntax of the English language.

The results also indicated that students still had difficulties in grammar although they have completed the grammar courses. The main difficulties are in adverb, prepositional phrases, noun clauses: subjunctives, tenses, and complex sentences with adverbial clauses.The next difficulty related with interference. Here the concept of automaticity in learning a language is not running at $100 \%$. This is evident from the amount of $48 \%$ of respondents who wrote the sentence in Bahasa Indonesia first before writing into English.

These difficulties are indeed part of the difficulty in learning a foreign language grammar. As noted by Ellis (2009: 144) the difficulty in learning the grammar can be grouped into three, namely: the difficulties associated with environmental factors of language, with linguistic factors, and psychological factors. Based on this theory, students of English Education encountered difficulties associated with linguistic and environmental factors when learning English grammar. Psychological factor is not a problem for students in learning it. 


\subsection{The Approaches used in Teaching Grammar}

The lectures used deductive, inductive, structural and communicative approaches. Three lecturers use deductive and inductive approaches. Communicative approaches were used by 2 lecturers, and only 1 lecturer used structural approach. From the finding it can be concluded that the lecturers apply not merely a traditional approaches. The lecturers are aware that deductive approach only is not enough. They combine some approaches in teaching grammar. Although students needed variation of approaches, they stated that they were comfortable with the deductive approach.

\subsection{Students' Grammar Mastery}

Overall the students' mastery of grammar on completing the grammar course is at the fair level. From a more detailed analysis it is known that the higher the level of grammar studied the more obstacles encountered by the students.

\section{Conclusion}

Based on the results of research and discussion, the conclusion can be drawn as follows:

1. In the case of the use of learning methods, the students proved to be suitable to the method used by lecturers, namely by providing an understanding of pattern or sentence formula first. This means more students feel comfortable learning grammar using deductive learning approach that has become a habit in schools for a long time.

2. There are some aspects of grammar that become problems for the students, such as: the differences in structure between Indonesian and English. This fact gives effect to the difficulty faced by the students in understanding the structure of English; students still have difficulty related to adverb, prepositional phrases, noun clauses: subjunctives, tenses, and complex sentences with adverbial clauses; and the interference of mother tongue.

3. Level of Students' Grammar mastery

Based on the results, it can be concluded that the students' grammar mastery in general is fair.

\section{REFERENCES}

Brinton, J.L. 2000. The Structure of Modern English: a linguistic introduction. The Netherland: John Benjamin Publishing Co.

Cook,V. 2008. Second language learning and teaching. London: Hodder Education.

Ellis, Rod. 2009. "Investigating Learning Difficulty in Terms of Implicit and Explicit Knowledge" dalam David Singleton Implicit and Explicit Knowledge in Second Language Learning, Testing and Teaching. Great Britain: Short Run Press Ltd.

Freeman- Diane Larsen 2009. "Teaching and Testing Grammar" dalam Machael H. Long and Catherine J. Doughty (ed). The handbook of language teaching. United Kingdom: Blackwell Publishing Ltd.

Harmer, J. (2007). How to teach English. London: Pearson Education Limited.

Nassaji, Hossein and Sandra Fotos. (2007). "Issues in form-focused instruction and teacher education" dalam Sandra Fotos and Hossein Nassaji (ed). Form-focused instruction and teacher education Studies in honour of Rod Ellis. Oxford: Oxford University Press.

Richards, J.C. and Schmidt,R. 2010. Longman dictionary of language teaching and applied

linguistics. Fourth edition. Great Britain: Pearson Education Limited.

Weaver,C. 1996. Teaching grammar in context. Heinemann.

Yule, G.2006. The study of a language. New York : Cambridge University Press. 